\title{
Effect of several patterns of floating stone columns on the bearing capacity and porewater pressure in saturated soft soil
}

\author{
Mahdi Karkush * and Anwar Jabbar \\ Civil Engineering Department, University of Baghdad, Baghdad, Iraq. \\ *Corresponding Author: mahdi_karkush@coeng.uobaghdad.edu.iq
}

Submitted : 12/06/2020

Revised :05/07/2021

Accepted : 15/07/2021

\begin{abstract}
One of the common geotechnical problems is the construction on soft soil and the improvement of its geotechnical properties to meet the design requirements. A stone column is one of the well-known techniques used to improve the geotechnical properties of soft soils. Sometimes, thick layers of soft soil imposed the designer to use floating stone columns for improvement of such soil; in this case, the designer will lose the end bearing of the stone column. In this study, the effects of several patterns of floating stone columns distribution under footing on the bearing capacity of soil and the distribution of excess porewater pressure are investigated. The soft soil used in this study has a very low undrained shear strength $\left(\mathrm{c}_{\mathrm{u}}\right)$ of $5.5 \mathrm{kPa}$ and improved by several patterns of stone columns (single, two-linear, triangular, square, and quadrilateral). The stone column has a length of $180 \mathrm{~mm}$ and a diameter of $30 \mathrm{~mm}$. The material of the stone column is poorly graded sand that has an angle of internal friction $\left(48.5^{\circ}\right)$ at a relative density of $65 \%$. The results indicated a significant increase in the ultimate bearing capacity of soft soil when treated with floating stone columns despite the small ratio of area replacement and reducing the excess porewater pressure and settlement. Also, the ultimate bearing capacity of soil calculated from experimental work is compared with the corresponding values obtained from the proposed equations in the previous studies to evaluate the validity of using such equations.
\end{abstract}

Keywords: Stone columns; Floating; Bearing capacity; Soft soil, Porewater pressure.

\section{INTRODUCTION}

The soft clayey soils are widely spread around the world, and such soils are located in the middle and southern regions of Iraq, especially in areas close to the marshes. The growth of population and rapid expansion of cities make using such soil important as construction material or foundation for different projects, so one of the key solutions is improving the geotechnical properties of soft soils. There are many techniques can be used for the improvement of soft soil. Stone columns are used to improve the soft clay soil has undrained shear strength $\left(\mathrm{c}_{\mathrm{u}}\right)<10 \mathrm{kPa}$ and subjected to different types of loading. Stone columns are used to increase the shear strength of soft soil strength, reduce and expedite the consolidation of soil, and reduce the liquefaction potential of soils. In the case of thick soft layer with a depth greater than $25 \mathrm{~m}$, the stone columns do not reach the stable layer of soil, so they are called floating stone columns (Datye, 1982; Abdullah et al., 2020; Karkush and Jabbar, 2021). 
Datye (1982) stated that stone columns can mount the loads and may be constructed in short intervals like floating pillars compared to the deep foundations. In areas where deep foundations are exposed to negative skin friction, it is preferred to use stone columns to make the foundations above it more supportable to drag force. Due to the effectiveness and economic efficiency of stone columns in improving the geotechnical behavior of soil, they can be implemented under roads, railways, and embankments (Unnikrishnan et al., 2002; Gadouri et al., 2019; Dong et al., 2019). Also, the stone columns can be used for the deep improvement of soft soil; therefore, this technique is widely used in the treatment of soft soil under railways to control the excess deformation and porewater pressure (Sivakumar et al., 2010; Fatahi et al., 2012; Karkush and Jabbar, 2021).

A statistical equation had been proposed to estimate the ultimate bearing capacity of soft soil treated with floating stone columns using the Statistical Package for the Social Sciences (SPSS) program. The data used in this analysis were obtained from experimental work and collected from previous studies. The proposed equation is applicable for clays that have undrained shear strengths in the range (4-25) kPa and with several aspect ratios of length to the diameter of the stone column (Fattah et al., 2017). Many previous studies stated that stone columns are affected by many factors such as the ratio of area replacement, length, and diameter of the column, the stiffness of the column and the surrounding soil, the concentration of stress between the columns, and the installation process. Also, the improvement of soft soil using stone columns mostly depends on the end bearing of stone columns and confinement stress applied to the surrounded soil under the static loads, but a little bit of information is available about floating columns' behavior in thick layers of soft soils (Elmeligi et al., 2021; Bailappanavar et al., 2021). The main objective of this work is to investigate the effects of several patterns of distribution of floating stone columns under footing withstand static loading. The experimental work is devoted to obtaining the load-settlement curves for foundations constructed on a thick soft layer and improved with several patterns of stone columns. Also, the distribution of excess porewater pressure with depth is calculated experimentally during the application of load on the footing. Finally, the work is extended to evaluate some of the proposed equations in the literature to assess the ultimate bearing capacity of soil treated with stone columns.

\section{USED MATERIALS}

\section{Soft Soil}

The soil samples were obtained from a depth of $9 \mathrm{~m}$ below the ground surface and the groundwater table encountered at a depth of 2-3 m. The geotechnical properties of soft soil used in tests are listed in Table 1 . The coefficient of permeability of soft soil is $1.45 \mathrm{E}-08 \mathrm{~cm} / \mathrm{min}$, which is calculated indirectly from the data of the 1D consolidation test. The unconfined compression strength test results conducted according to ASTM D 2166-00 on disturbed and undisturbed soil samples are shown in Figure 1. The undrained shear strength of undisturbed soft soil is $5.5 \mathrm{kPa}$, and the corresponding axial strain is $6 \%$. The soft soil sample's sensitivity is 1.13 and can be classified as slightly sensitive (Das, 2013). The undrained shear strength of soft soil (cu) is $11 \mathrm{kPa}$. measured from the unconsolidated undrained triaxial test as shown in Figure 2. This value is higher than that measured by the unconfined compression strength test due to the presence of confining pressure which help to increase the deviator stress at failure. 
Table 1. The geotechnical properties of natural soft soil.

\begin{tabular}{|c|c|c|c|c|c|}
\hline Property & Value & ASTM & Property & Value & ASTM \\
\hline Liquid limit, $\%$ & 35 & \multirow{2}{*}{ D4318 } & Maximum dry density, $\mathrm{kg} / \mathrm{m}^{3}$ & 1753 & \multirow{2}{*}{ D1557 } \\
\hline Plastic limit, $\%$ & 19 & & Optimum water content, $\%$ & 19.0 & \\
\hline Plasticity index, $\%$ & 16 & - & Soil symbol according to USCS & $\mathrm{CL}$ & D2487 \\
\hline Liquidity index, $\%$ & 0.625 & - & Initial void ratio & 0.78 & \multirow{5}{*}{ D 2435} \\
\hline Specific gravity & 2.7 & D854 & Compression index & 0.166 & \\
\hline Sand content, $\%$ & 10.0 & \multirow{3}{*}{ D422 } & Swelling index & 0.027 & \\
\hline Silt content, $\%$ & 50.0 & & Coefficient of volume change, $\mathrm{m}^{2} / \mathrm{MN}$ & 0.49 & \\
\hline Clay content, $\%$ & 40.0 & & Coefficient of consolidation, $\mathrm{cm}^{2} / \mathrm{sec}$ & 0.05 & \\
\hline
\end{tabular}

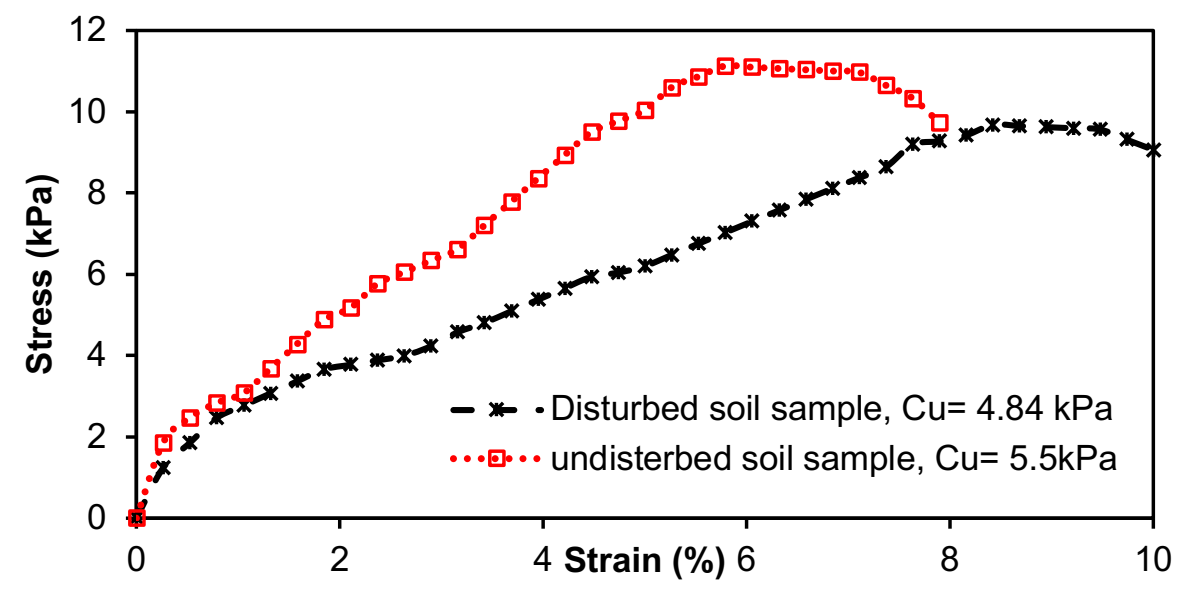

Figure 1. Stress-strain curves were obtained from unconfined compressive strength tests.

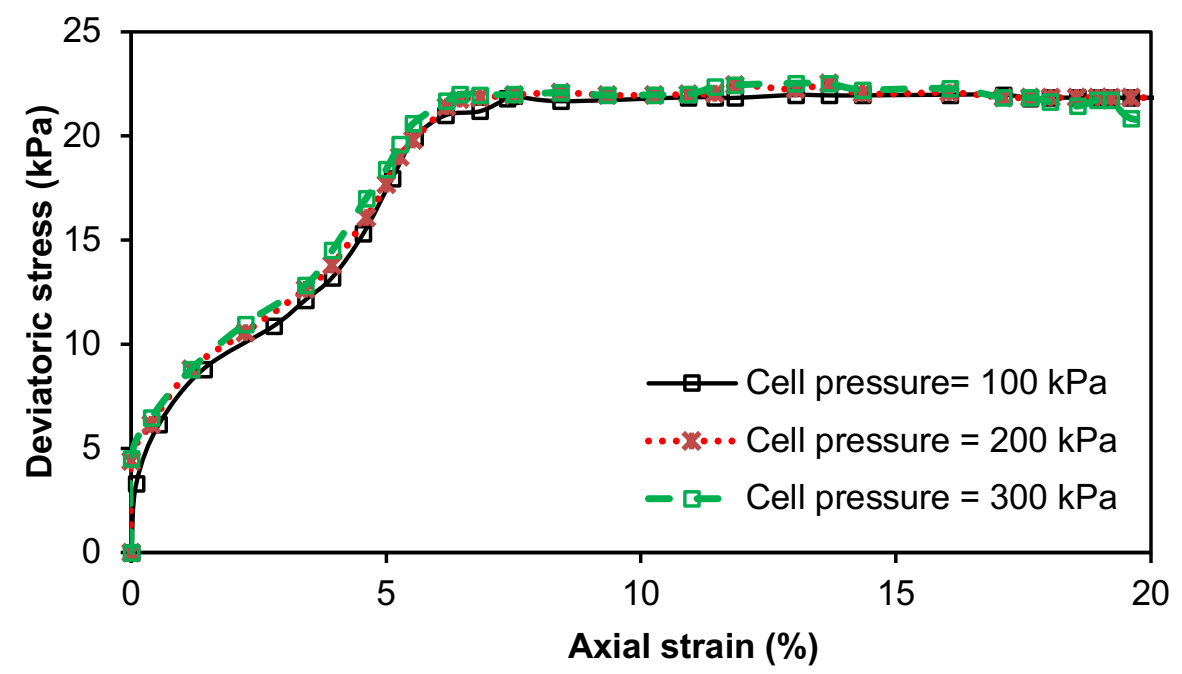

Figure 2. Stress-strain curves were obtained from unconsolidated undrained triaxial tests. 


\section{Stone Column}

Based on the results of previous studies, the appropriate fill material used in the construction of stone columns must have a friction angle more than $35^{\circ}$ (Bergado and Lam, 1987; Juran and Guermazi, 1988; Rajagopal et al., 1999; ASTM, 2003; Kim and Lee, 2005; Gniel and Bouazza, 2009; Madun et al., 2012; Emrah, 2012; Hanna, 2013; Karkush et al., 2018; Karkush and Yassin, 2020). Accordingly, a poorly graded sand of an appropriate size to the dimension of stone column is selected to simulate the stone column material, where sand is widely used in previous studies. The geotechnical properties of stone column material are listed in Table 2.

Table 2. Physical and mechanical properties of stone column material.

\begin{tabular}{|c|c|c|c|c|c|}
\hline Property & Value & ASTM & Property & Value & ASTM \\
\hline Maximum dry density, $\mathrm{kg} / \mathrm{m}^{3}$ & 1947 & $\mathrm{D} 4253$ & $\mathrm{D}_{10}, \mathrm{~mm}$ & 0.9 & \\
\hline Minimum dry unit weight, $\mathrm{kN} / \mathrm{m}^{3}$ & 1468 & $\mathrm{D} 4254$ & $\mathrm{D}_{30}, \mathrm{~mm}$ & 1.3 & - \\
\hline Dry density at Dr $=65 \%, \mathrm{~kg} / \mathrm{m}^{3}$ & 1753 & - & $\mathrm{D}_{50}, \mathrm{~mm}$ & 1.75 \\
\hline Coefficient of uniformity $(\mathrm{Cu})$ & 2.22 & - & $\mathrm{D}_{60}, \mathrm{~mm}$ & 2.0 & \\
\hline Coefficient of curvature $(\mathrm{Cc})$ & 0.94 & - & Suitability number & 3.0 & - \\
\hline Angle of internal friction $(\varphi),^{\circ}$ & 48.5 & $\mathrm{D} 3080$ & Specific gravity & 2.65 & D854 \\
\hline
\end{tabular}

It is challenging to construct uniform stone column with a relative density higher than $80 \%$; therefore, the relative density of sand used in the stone column is selected to be $65 \%$ (Frikha et al., 2015). The stone column diameter (d) and spacing between columns measured center to center (S) are selected to be 30 and $75 \mathrm{~mm}$ respectively. The typical aspect ratio of length/diameter (L/d) is preferred to be in the range between 6 and 10, so the length of the column is selected according to this ratio. There is no respectable increase in soil bearing capacity treated with stone columns when L/d ratio greater than 10 (McKelvey et al., 2004). After selecting the appropriate dimensions of a stone column, selecting the fill material of stone column is necessary. Generally, the typical ratio of stone column diameter to the particle size of fill material (d/dg) is ranged from 12 to 40 (Muir et al., 2000; Shahu and Reddy, 2011). Accordingly, the stone column fill material is sand has sizes in the range $(0.7-2.5) \mathrm{mm}$, which satisfying the $\mathrm{d} / \mathrm{dg}$ ratio (12 to 43).

\section{EXPERIMENTAL MODEL}

The physical model is manufactured to investigate several patterns of floating stone columns on the loadsettlement behavior of soft soil under raft footing as shown in Figure 3. The porewater pressure readings are measured by a piezometer fixed at the bottom of the soil bed in the soil container for each load increment and three porewater pressure transducers fixed on the sidewall of soil box. 


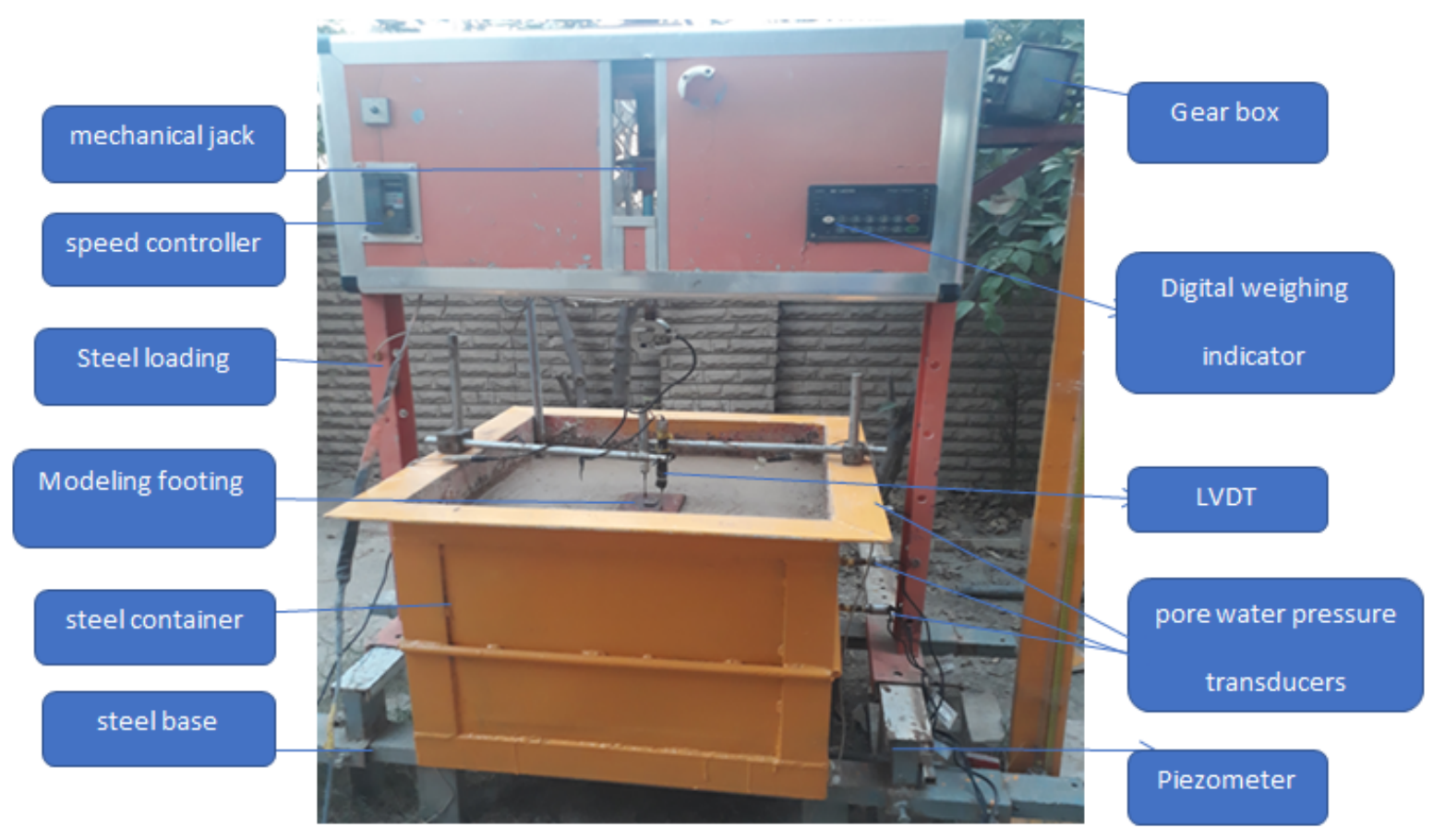

Figure 3. The physical model for static loading tests.

\section{Steel box and Instruments}

To simulate the field conditions in the laboratory, a suitable measuring factor should be selected; in reality, it is not possible to maintain appropriate measurement factors in physical model tests that fully meet all factors governing the response of the prototype (Hu, 1995). Based on the concept of the unit cell, the area replacement ratio (As) and the diameter ratio $(\mathrm{N})$ can be related by the following equation (Ashour, 2016).

$A_{s}=A_{c o l} / A=(d / D)^{2}=1 / N^{2}$

Where

As $=(\mathrm{d} / \mathrm{m} \cdot \mathrm{S})^{2}$ and $\mathrm{m}$ is a constant depends on the distribution pattern of columns;

$\mathrm{A}_{\text {col: }}$ cross-sectional areas of stone columns;

A: cross-sectional areas of soft soil;

$\mathrm{d}$ : diameter of the stone column;

$\mathrm{L}$ : the length of the column;

D: equivalent diameter of the unit cell;

The normal value of area replacement ratio in the range 5 to $30 \%$ (Ashour, 2016). This range of area replacement ratio delivers a diameter ratio $(\mathrm{N})$ between 2 to 5 and this ratio corresponds to the findings of Hugher and Withers (Hugher and Withers, 1974). Hugher and Withers (1974) demonstrated that the stone column could increase the strength of the soft soil within a distance of up to $2.5 \mathrm{~d}$. The soil container dimensions are $(700 \times 700 \times 600) \mathrm{mm}$, where these dimensions are selected to prevent stresses from reaching the boundaries of a container when the zone of 
pressure starts from two-thirds of the length of the column and extended using the method of 2:1 (Frikha et al., 2015). To satisfy the above conditions, a raft foundation of dimensions $(120 \times 120) \mathrm{mm}$ can be used in tests, so the parameter $\mathrm{N}$ in Eq. 2 equals 2.8. According to the stone column diameter $(30 \mathrm{~mm})$ and $\mathrm{N}=2.8$, the area replacement ratio is $12.5 \%$. The following instruments are used in the manufactured model:

- The load cell of $1000 \mathrm{~kg}$ capacity and $50 \mathrm{~g}$ accuracy connected with a digital indicator.

- Porewater pressure transducers are fixed on the sidewall of soil box at distances (50, 200, and 350) $\mathrm{mm}$ measured from the surface of the soil and connected with a digital indicator.

- Two LVDTs connected with digital indicators.

\section{Soil Bedding}

The dry mass of soft soil required to fill the steel container was calculated according to the field unit weight and natural moisture content. The dry mass of soil was divided into 5 layers, each layer of $8 \mathrm{~cm}$ thickness, and weighs $75.6 \mathrm{~kg}$ based on the field density of $1.93 \mathrm{~g} / \mathrm{cm}^{3}$ and natural moisture content of $29 \%$. This quantity of soil is divided into three parts, each of $25.2 \mathrm{~kg}$ and tamped well with uniformly distributed 16 blows by a special hammer of dimensions $(250 \times 250) \mathrm{mm}$ and weighs $9.75 \mathrm{~kg}$. After putting the last layer of soil, the surface of the soil has been scraped to get a flat surface as shown in Figure 4. The bedding soil in the steel box is fully saturated and covered with a nylon layer to prevent any loss of moisture and left for (8-10) days for curing and regain its strength (Fattah et al., 2017).

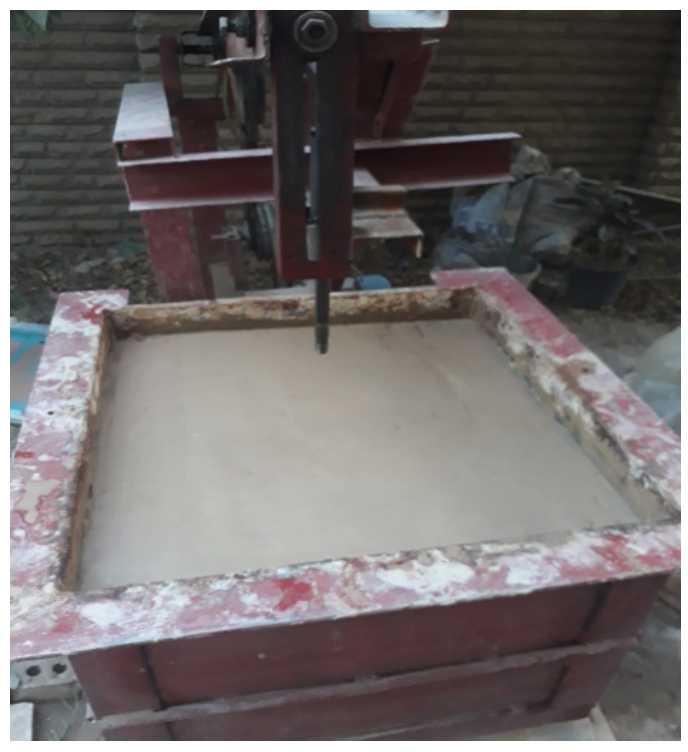

Figure 4. Soil bed in the steel container.

A specific number of holes of $30 \mathrm{~mm}$ diameter are drilled in the soil bed using a hollow steel pipe of an outer diameter of $30 \mathrm{~mm}$ coated with lubrication oil and pushed down to reach the required depth of $180 \mathrm{~mm}$. Then, a predetermined mass of the sand is poured into the hole with tamping to get the desired density of sand. The weight of sand per column was calculated according to the dry density of sand $\left(1.714 \mathrm{~g} / \mathrm{cm}^{3}\right)$ and the relative density of stone column material is selected to be $65 \%$. A steel rod of $1.5 \mathrm{~kg}$ weight was used to compact the sand in the stone column hole. The sand was divided into four layers; each layer was compacted with 10 blows by the rod, which dropped from a distance of $40 \mathrm{~mm}$. The designation and distribution patterns of stone columns under footing in soft soil are given in Table 3 and Figure 5. 
Table 3. The testing program was adopted for this study.

\begin{tabular}{|c|c|c|c|c|c|}
\hline Symbol & $\mathbf{c}_{\mathbf{u}}(\mathbf{k P a})$ & No. of stone columns & As $(\%)$ & Hc/Hs & Pattern \\
\hline SL0 & 5.5 & 0 & 0.0 & 0.00 & Non \\
\hline SL1 & 5.5 & 1 & 4.9 & 0.45 & Single \\
\hline SL2 & 5.5 & 2 & 9.82 & 0.45 & Linear \\
\hline SL3 & 5.5 & 3 & 14.7 & 0.45 & Triangular \\
\hline SL4 & 5.5 & 4 & 19.6 & 0.45 & Square \\
\hline SL5 & 5.5 & 4 & 19.6 & 0.45 & Quadrilateral \\
\hline
\end{tabular}
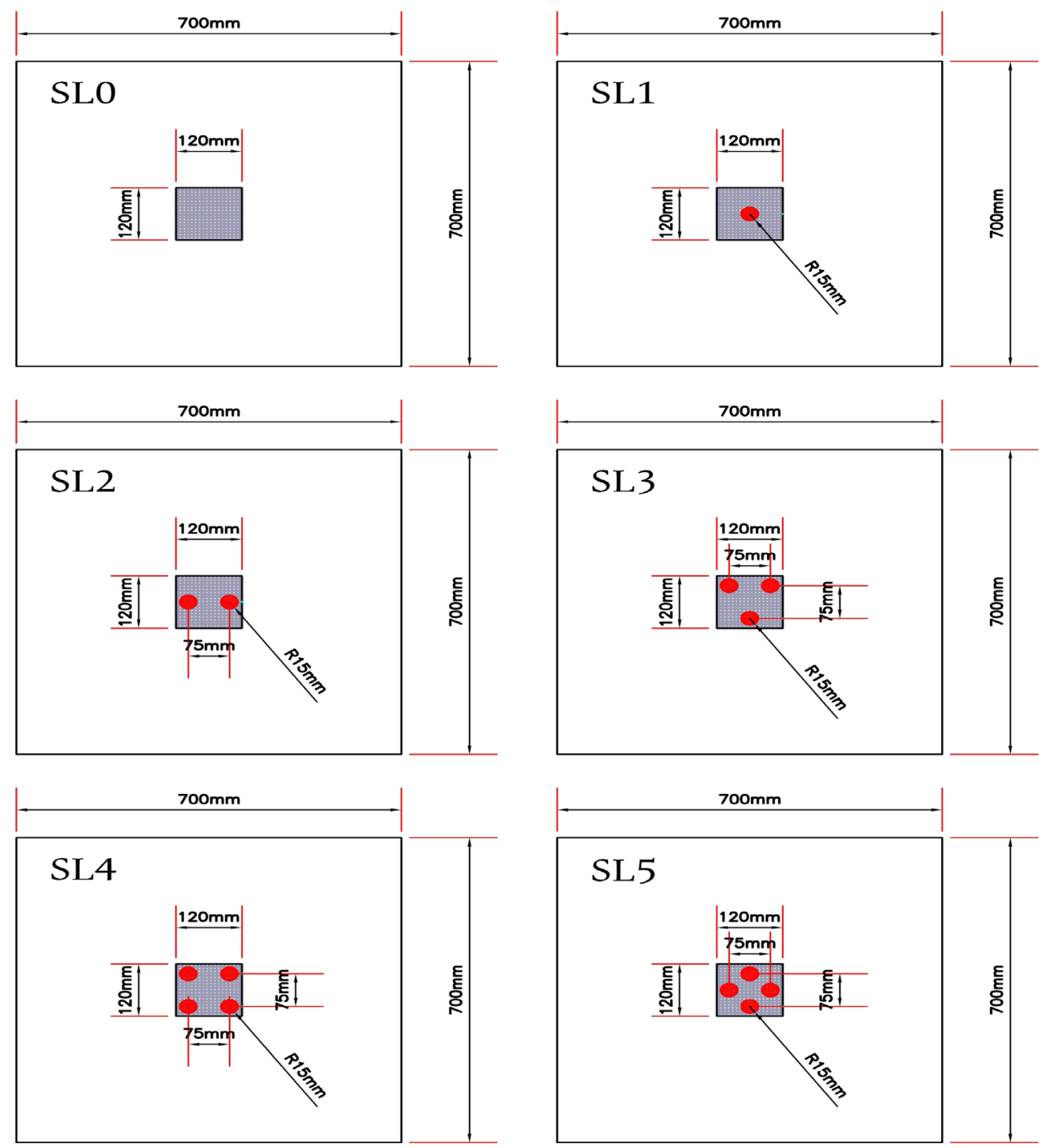

Figure 5. Distributions patterns of stone columns under raft footing in soft soil. 


\section{Testing Procedure}

The following points can summarize the procedure adopted in testing the raft footing under static loading constructed on soft clayey soil reinforced with several patterns of floating stone columns:

- $\quad$ Put the bedding soil in the box according to the field unit weight and moisture content as described in soil bedding;

- Constructing the floating stone columns according to the required pattern of stone columns distribution;

- Put a raft footing model of dimensions $(120 \times 120 \times 10) \mathrm{mm}$ in the center of the steel box on the surface of clay soil, where the centerline of the footing coincides with the centerline of the load cell and hydraulic jack over stone columns;

- Fix two linear variable displacement transducers (LVDTs) to measure the settlements of the raft footing;

- Apply the load increment using a hydraulic jack, where the loading rate is constant $(1 \mathrm{~mm} / \mathrm{min})$. The loading increment maintained for $24 \mathrm{hrs}$. or until the reading of settlement became constant. During this period, the load and settlements are recorded;

- The porewater pressure is recorded at the end of each load increment by using three porewater pressure transducers placed at different heights $(50,200$, and 350) $\mathrm{mm}$ from the top of the soil surface and by a piezometer tube fixed at the bottom of soil box.

\section{RESULTS AND DISCUSSION}

Six soil specimens were prepared to measure the improvement in the strength of soft soil, reduction in soil compressibility, and excess porewater pressure distribution. The soil specimens were reinforced with five patterns of floating stone columns. The load was applied at the top of the soil surface on a square plate of dimensions $(120 \times 120)$ $\mathrm{mm}$. The results obtained from the physical model are the variation of settlement and porewater pressure with applied load. The distribution of stone columns can be divided into three main categories: single stone column (SL1), linear distribution of stone columns (SL2), and a group of stone columns (SL3, SL4, and SL5). The load-settlement relationship for several patterns of distribution of floating stone columns is shown in Figure 6. Based on the results of tests presented in Figure 6, increasing the ultimate bearing capacity of soil with increasing the number of stone columns is observed, but the configuration of the distribution of stone columns under footing has negligible effect. The ultimate bearing capacity of soil is assumed to be corresponding to a settlement of $20 \%$ of the footing width. The ultimate bearing capacity of soil increased by $76,97,132,148$, and $145 \%$ for soil samples SL1, SL2, SL3, SL4, and SL5, respectively. Using four stone columns with a square pattern is more efficient than using a triangular pattern, where the difference between the two patterns is about 3\% despite the same area replacement ratio of $19.6 \%$.

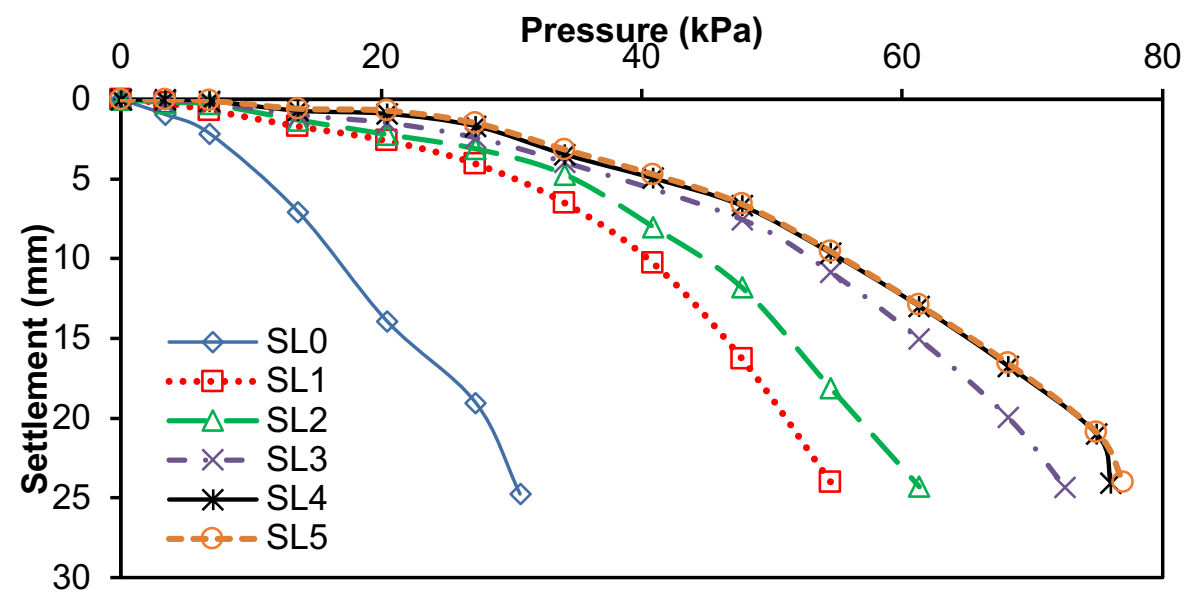

Figure 6. Settlement versus pressure for soil samples reinforced with several patterns of floating stone columns. 
The ultimate bearing capacity (qult) of natural soft soil sample (SL0) can be calculated by Terzaghi's Eq. 2 .

$\mathrm{q}_{\mathrm{ult}}=\mathrm{N}_{c} \mathrm{c}_{\mathrm{u}}$

$\mathrm{Nc}$ is the bearing factor for clay and equals 5.14 and $\mathrm{c}_{\mathrm{u}}$ is the undrained shear strength of the soft soil $(5.5 \mathrm{kPa})$. The ultimate bearing capacity of natural soft soil calculated by Eq. $2(28.27 \mathrm{kPa})$ is well agreed with the value calculated experimentally $(31 \mathrm{kPa})$. Also, the bearing capacity of soft soil reinforced with stone columns can be calculated according to the following equations presented in the literature:

a) Bowels (1996) presented an approximate formula for the ultimate bearing capacity of soft soil treated with stone columns:

$\mathrm{q}_{\mathrm{ult}}=\mathrm{K}_{\mathrm{p}}\left(4 \mathrm{c}_{\mathrm{u}}+\sigma_{\mathrm{r}}^{\prime}\right) \mathrm{A}_{\mathrm{c}} \mathrm{N}_{\mathrm{s}} / \mathrm{A}_{\mathrm{f}}$

Where

$\mathrm{K}_{\mathrm{p}}$ : coefficient of passive earth pressure $=\tan ^{2}(45+\varphi / 2)$.

$\varphi$ ': drained angle of internal friction of stone column material;

$\mathrm{c}_{\mathrm{u}}$ : undrained shear strength of soil;

$\sigma_{r}^{\prime}$ : effective radial stress measured by pressure meter; if this value is not available, it can use $6 c_{u}$;

$\mathrm{A}_{\mathrm{c}}$ : cross-sectional area of the stone column.

Af: cross-sectional area of the footing.

$\mathrm{N}_{\mathrm{s}}$ : number of stone columns.

b) Bouassida et al. (1995) developed an equation for calculating the bearing capacity of a group of stone columns.

$\mathrm{q}_{\mathrm{ult}}=4 \mathrm{c}_{\mathrm{u}}+2 \mathrm{~A}_{\mathrm{s}}\left(\mathrm{c}_{\mathrm{u}}\left(\mathrm{K}_{\mathrm{p}}-2\right)+\mathrm{c}_{\mathrm{s}} \sqrt{\mathrm{K}_{\mathrm{p}}}\right)$

where

$\mathrm{c}_{\mathrm{s}}$ is the cohesion of stone column material,

As: the area replacement ratio,

c) Fattah et al. (2017) proposed an equation for calculating the bearing capacity of stone columns based on a statistical analysis of collected data.

$$
\mathrm{q}_{\mathrm{ult}}=15.34 \mathrm{c}_{\mathrm{u}}^{0.401} \mathrm{~A}_{\mathrm{s}}^{0.266} \mathrm{~N}_{\mathrm{s}}^{0.084}(\mathrm{~L} / \mathrm{d})^{0.526}
$$

where

$\mathrm{c}_{\mathrm{u}}$ is the undrained shear strength of soil in $\mathrm{kPa}$,

$\mathrm{L} / \mathrm{d}$ is the length to diameter ratio of the stone column.

The results of ultimate bearing capacity of soft soil calculated using Terzaghi equation and for soil improved by several patterns of stone columns calculated from experimental work are compared with those calculated theoretically using Eqs. 3, 4, and 5 given in Table 4. The modified Davison approach was also used to calculate the bearing capacity of soil reinforced with several patterns of stone columns from the load-settlement curves (Davisson, 1972). The ultimate bearing capacity of reinforced soil calculated using the Davison approach agreed well with the experimental results, ranging from 11.7 to $22 \%$. This deviation range is arbitrary and not related to the pattern of distribution stone columns under the footing. One of the old equations is used to calculate the bearing capacity of soil reinforced with stone columns proposed by Bowels (1996), but this equation underestimates experimental results 
ranging -2.17 to $-65.49 \%$. This deviation range is very high and not accepted because this equation neglected the spacing between stone columns, length of stone columns, and pattern of distribution of stone columns under the footing.

Also, the equation proposed by Bouassida et al. (1995) gives an underestimation (-15.59 to $-39.95 \%)$ for the bearing capacity of soil reinforced with stone columns. In this equation, the effect of spacing between columns, the stone column diameter, the number of stone columns, and the length of stone columns are replaced by one parameter, which is the area replacement ratio; this ratio is not sufficient to substitute these four essential parameters. Using Eq. 5, proposed by Fattah et al. (2017), shows good agreement with the results of experimental work. This equation is derived by regression analysis of several studies in this field, especially the construction of stone columns in soft clay and/or floating stone columns. The deviation between the ultimate bearing capacity of soil predicted by Eq. 5 and experimental work ranged between 0.67 and $10.74 \%$. Generally, all the proposed equations (3 to 5) do not take the effects of the distribution of stone columns under the footing. Therefore, the square pattern (SL4) results are the same as for the quadrilateral pattern (SL5). It is recommended to make a wide investigation to find out an acceptable general equation that can be used for preliminary estimation of the ultimate bearing capacity of soil treated with floating stone columns.

Table 4. Comparison of bearing capacity calculated from experimental work with several theoretical solutions.

\begin{tabular}{|c|c|c|c|c|c|c|c|c|c|c|}
\hline \multirow{2}{*}{ Symbol } & \multirow{2}{*}{ Ns } & \multirow{2}{*}{$\begin{array}{c}\text { Exp. qult } \\
\mathbf{k P a}\end{array}$} & \multicolumn{2}{|c|}{ Davisson (1972) } & \multicolumn{2}{|c|}{ Bowels (1995) } & \multicolumn{2}{|c|}{$\begin{array}{c}\text { Bouassida et al. } \\
\text { (1995) }\end{array}$} & \multicolumn{2}{|c|}{$\begin{array}{c}\text { Fattah et al. } \\
\quad(2017)\end{array}$} \\
\hline & & & $\begin{array}{r}\text { qult } \\
\mathbf{k P a}\end{array}$ & $\begin{array}{c}\% \\
\text { dev. }\end{array}$ & $\begin{array}{r}\text { qult } \\
\mathbf{k P a}\end{array}$ & $\begin{array}{c}\% \\
\text { dev. }\end{array}$ & $\begin{array}{r}\text { qult } \\
\mathbf{k P a}\end{array}$ & $\begin{array}{c}\% \\
\text { dev. }\end{array}$ & $\begin{array}{r}\text { qult } \\
\mathbf{k P a}\end{array}$ & $\begin{array}{c}\% \\
\text { dev. }\end{array}$ \\
\hline SLO & - & 31.0 & - & - & - & - & - & - & - & - \\
\hline SL1 & 1 & 54.5 & 47.70 & 14.0 & 18.81 & -65.49 & 32.73 & -39.95 & 54.87 & 0.67 \\
\hline SL2 & 2 & 61.0 & 50.00 & 22.0 & 37.62 & -38.33 & 43.45 & -28.76 & 67.55 & 10.74 \\
\hline SL3 & 3 & 72.0 & 62.00 & 16.0 & 56.43 & -21.63 & 54.18 & -24.75 & 76.29 & 5.95 \\
\hline SL4 & 4 & 76.9 & 68.00 & 13.0 & 75.23 & -2.17 & 64.91 & -15.59 & 83.16 & 8.14 \\
\hline SL5 & 4 & 76.0 & 68.00 & 11.7 & 75.23 & -2.17 & 64.91 & -15.59 & 83.16 & 8.14 \\
\hline
\end{tabular}

The porewater pressure is measured during the period of loading on the footing at several depths of soil. With a stand piezometer pipe installed at the bottom of soil layer (PP1) and three PWP transducers installed at distances (50, 200, and 350) $\mathrm{mm}$ from the soil surface, these transducers are fixed on the side wall of soil container. The first transducer fixed at $50 \mathrm{~mm}$ from the soil surface was not sensitive for porewater pressure during the tests, where the short path of drainage helps the quick dissipation of PWP. Figure 7 shows the variation of excess PWP, measured by piezometer (PP1) during applied loads for the tested soil samples. The PWP was constant about $4 \mathrm{kPa}$ at the beginning of tests because the piezometer measures the static PWP before starting the load application. Using stone columns to improve soft soil expedites the consolidation rate because the stone columns work as drainage wells. The selection of stone columns under footing plays an essential role in shortening the drainage paths and reducing the time required for consolidation. The comparison of excess porewater pressure values at a certain stress level, for example, at stress, equals $34.05 \mathrm{kPa}$, and the porewater pressure was $4.99 \mathrm{kPa}$ for SL1 and continues to decrease for SL2, SL3, and SL4 to become $3.94 \mathrm{kPa}$ for SL5. The same behavior was shown for a loading of $61.31 \mathrm{kPa}$. These results indicate that the quadrilateral and square patterns with four columns are good for providing the drainage path and reducing porewater pressure, but the more efficient for this purpose is using a quadrilateral pattern of distribution. 


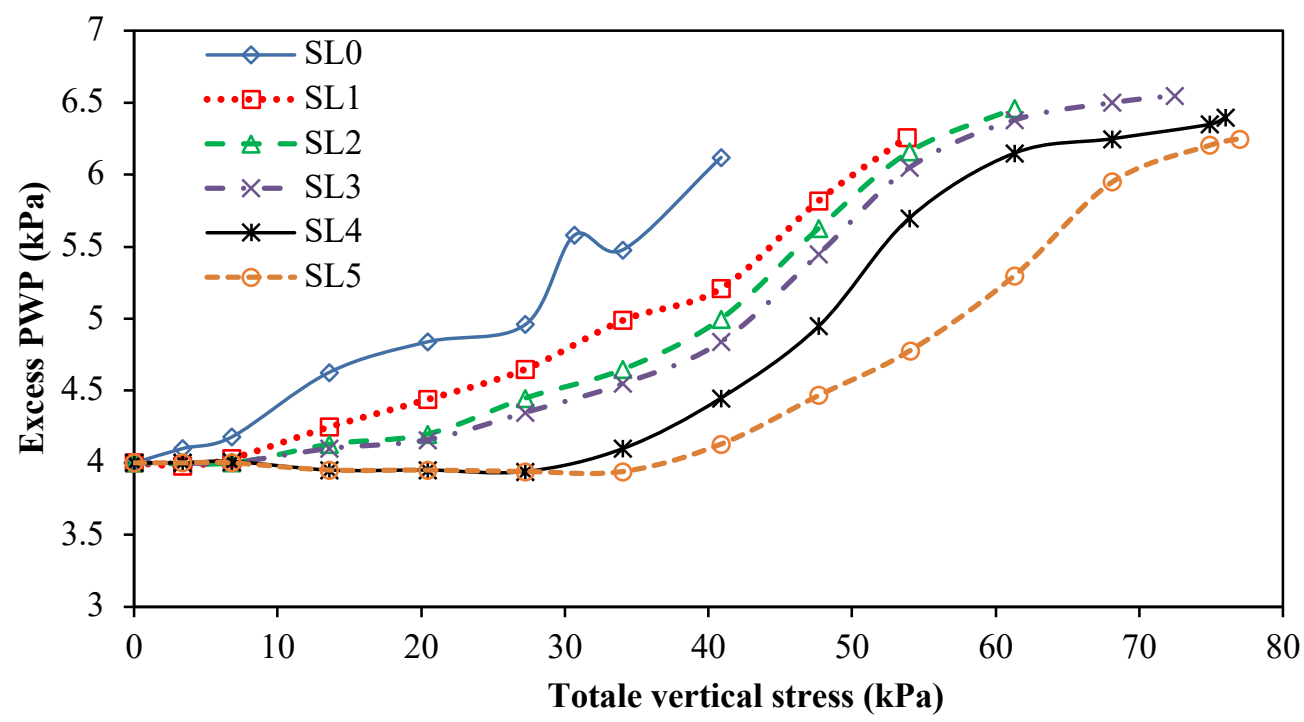

Figure 7. Variation of porewater pressure with applied loads measured by (PP1) method.

The variation of excess PWP with depth measured by PWP transducer and piezometer for the tested soil samples is shown in Figure 8. The stress level of $30.65 \mathrm{kPa}$ is the maximum stress applied on the natural soft soil, the stress level of $54.5 \mathrm{kPa}$ is maximum stress applied on soil reinforced with one column, and the stress level of $76.3 \mathrm{kPa}$ is maximum stress applied on soil reinforced with four columns in square and quadrilateral pattern. When the stone column is installed at $5 \mathrm{~cm}$ from the soil surface, it showed a little change in the measured porewater pressure and gradually decreased with increasing the applied loads. There was an increase in the porewater pressure measured with depth for the tested soil samples, but the PWP decreases with increasing the number of stone columns. The triangular pattern and square pattern showed the same trend and values of PWP with depth, but using a quadrilateral pattern shows the best behavior for porewater drainage compared to other suggested patterns in this study.

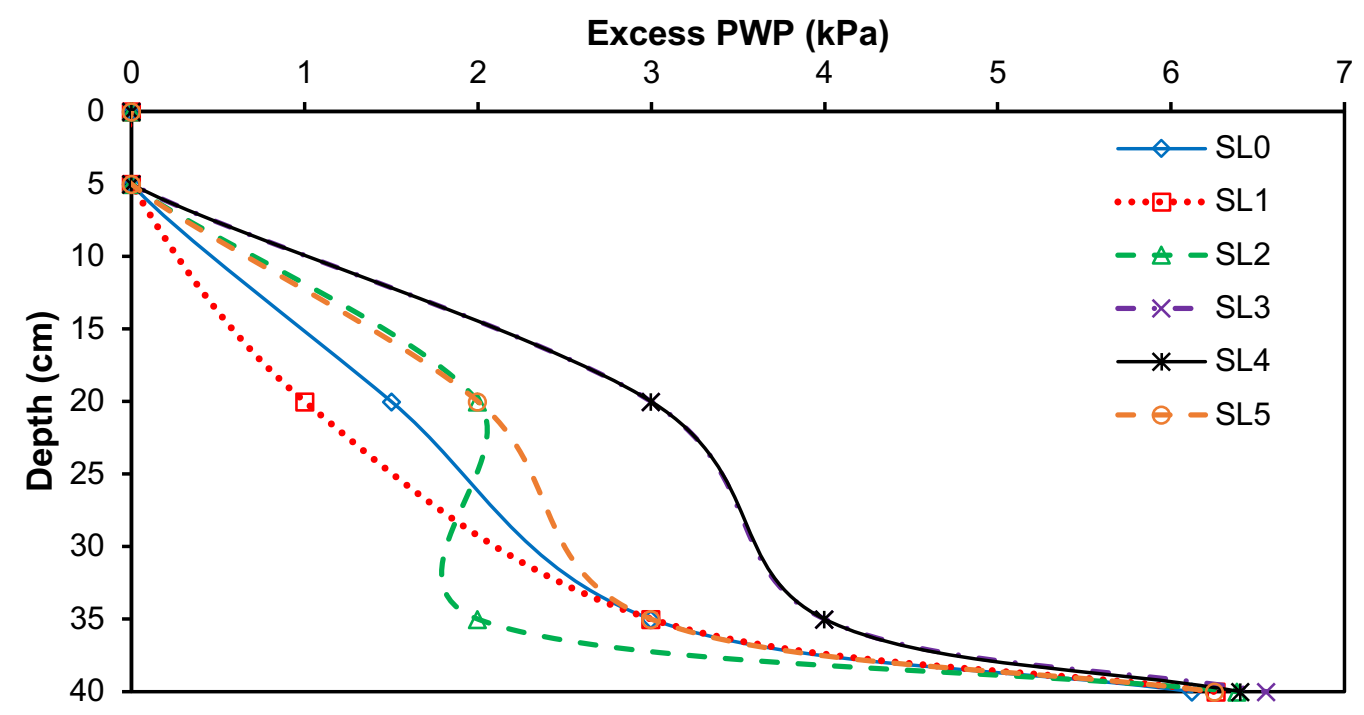

Figure 8. Variation of porewater pressure with depth at failure load. 


\section{CONCLUSIONS AND RECOMMENDATIONS}

The following points can summarize the effects of several patterns of distribution of floating stone columns on the ultimate bearing capacity of thick soft soil and distribution of porewater pressure with depth:

- The results of tests showed the ability to use floating stone columns to improve the ultimate bearing capacity of soft soil despite the small area replacement ratio, where the ultimate bearing capacity increased by 76,97 , 132,148 , and $145 \%$ for soil samples SL1, SL2, SL3, SL4, and SL5, respectively.

- The floating stone column's presence reduces the porewater pressure due to shortening the drainage pathways and time required for escape.

- The increase in the number of stone columns below the footing leads to an increase in the soil's ultimate bearing capacity due to increasing the area replacement ratio and increasing the stress concentration ratio on columns.

- The floating stone columns reduce the consolidation settlement corresponding to the failure load by $57 \%$ for the single floating stone column and $86 \%$ for the stone columns.

- There is no significant change in the improvement of the ultimate bearing capacity of soil between the square and quadrilateral patterns of stone columns, but there is a noticeable change in the excess porewater pressure generated during the loading. Using a quadrilateral pattern is more efficient than using a square pattern, although they have the same area replacement ratio.

- It is recommended to investigate the durability of floating stone columns and the effects of stone column material's dilatancy, studying the behavior of floating stone columns in the improvement of partially saturated soils.

\section{REFERENCES}

Abdullah, W., Janbaz, M., Miskewitz, R., Iacobucci, L., Francisco, K., Eid, W., \& Maher, A. 2020. Assessment of the suitability of Kuwait oil sands for beneficial reuse. Journal of Engineering Research, 8(1).

Ashour, S. 2016. The response of stone columns under the cyclic loading. Ph.D. dissertation, University of Birmingham.

ASTM 2003. Annual Book of American Society for Testing and Material Standards, ASTM Tech Publications.

Bailappanavar, N. I., Kumar, M., \& Chatterjee, K. 2021. Effect of Stone Columns on Strength and Consolidation Characteristics of Black Cotton Soil. KSCE Journal of Civil Engineering, 25(4), 1214-1228.

Bergado, D. T. \& Lam, F. L. 1987. Full scale load test of granular piles with different densities and different proportions of gravel and sand on soft Bangkok clay. Soils and foundations, 27(1), pp.86-93.

Bouassida, M., De Buhan, P. \& Dormieux, L. 1995. Bearing capacity of a foundation resting on a soil reinforced by a group of columns. Géotechnique, 45(1), pp.25-34.

Bowles, L. E. 1996. Foundation analysis and design. McGraw-hill.

Das, B. M. 2013. Advanced Soil Mechanics. CRC Press.

Datye, K.R. 1982. Settlement and bearing capacity of foundation system with stone columns. In Int. Symp. on Soil and Rock Improvement Techniques Including Geotextiles, Reinforced Earth, and Modern Piling Methods. Asian Institute of Technology.

Davisson, M. T. 1972. High Capacity Piles. Proceedings, Lecture Series, Innovations in Foundation Construction, ASCE, Illinois Section, Chicago, March 22, pp. 81-112.

Dong, J. G., Xu, G. Y., Lv, H. B., \& Yang, J. Y. 2019. Development of instrument for wetting-drying cycles of expansive soil under simulated loads and experimental research. Journal of Engineering Research, 7(3). 
EImeligi, K. H., Sabry, M. A., \& El-Sekelly, W. 2021. Stepped Loading of a Raft Foundation Supported on Deep Soft Clay Improved with Floating Stone Columns. In Advancements in Geotechnical Engineering (pp. 3243). Springer, Cham.

Emrah, M. S. 2012. A laboratory model study on settlement reduction of stone columns in soft clay. M.Sc. Thesis, School of Natural and Applied Sciences, Middle East Technical University.

Fatahi, B., Khabbaz, H. \& Le, T. M. 2012. Improvement of rail track subgrade using stone columns combined with geosynthetics. Advances in Transportation Geotechnics 2, p.40.

Fattah, M. Y., Al-Neami, M. A. \& Al-Suhaily, A. S. 2017. Estimation of bearing capacity of floating group of stone columns. Engineering science and technology, an international journal, 20(3), pp.1166-1172.

Frikha, W., Bouassida, M. \& Canou, J. 2015. Parametric study of a clayey specimen reinforced by a granular column. International Journal of Geomechanics, 15(5), p.04014078.

Gadouri, H., Harichane, K., \& Ghrici, M. 2019. Effect of the interaction between calcium sulphate and mineral additives on shear strength parameters of clayey soils. Journal of Engineering Research, 7(2).

Gniel, J. \& Bouazza, A. 2009. Improvement of soft soils using geogrid encased stone columns. Geotextiles and Geomembranes, 27(3), pp.167-175.

Hanna, A. M., Etezad, M. \& Ayadat, T. 2013. Mode of failure of a group of stone columns in soft soil. International Journal of Geomechanics, 13(1), pp.87-96.

Hu, W. 1995. Physical modelling of group behaviour of stone column foundations. Ph.D. Dissertation, University of Glasgow.

Hugher, J. M. O. \& Withers, N. J. 1974. Reinforcing of soft cohesive soils with stone columns. Ground engineering, 7(3).

Juran, I. \& Guermazi, A. 1988. Settlement response of soft soils reinforced by compacted sand columns. Journal of Geotechnical Engineering, 114(8), pp.930-943.

Karkush, M. O., \& Yassin, S. 2020. Using sustainable material in improvement the geotechnical properties of soft clayey soil. Journal of Engineering Science and Technology, 15(4), 2208-2222.

Karkush, M. O., Ali, H. A., \& Ahmed, B. A. 2018. Improvement of Unconfined Compressive Strength of Soft Clay by Grouting Gel and Silica Fume. In Proceedings of China-Europe Conference on Geotechnical Engineering (pp. 546-550). Springer, Cham.

Karkush, M., \& Jabbar, A. 2021. Behavior of floating stone columns and development of porewater pressure under cyclic loading. Transportation Infrastructure Geotechnology, 1-14.

Kim, B. I. \& Lee, S. H. 2005. Comparison of bearing capacity characteristics of sand and gravel compaction pile treated ground. KSCE Journal of Civil Engineering, 9(3), pp.197-203.

Madun, A., Jefferson, I., Foo, K. Y., Chapman, D. N., Culshaw, M. G. \& Atkins, P. R. 2012. Characterization and quality control of stone columns using surface wave testing. Canadian Geotechnical Journal, 49(12), pp.1357-1368.

McKelvey, D., Sivakumar, V., Bell, A. \& Graham, J. 2004. Modelling vibrated stone columns in soft clay. Proceedings of the Institution of Civil Engineers-Geotechnical Engineering, 157(3), pp.137-149.

Muir Wood, D., Hu, W. \& Nash, D. F. 2000. Group effects in stone column foundations: model tests. Geotechnique, 50(6), pp.689-698.

Rajagopal, K., Krishnaswamy, N. R. \& Latha, G. M. 1999. Behaviour of sand confined with single and multiple geocells. Geotextiles and Geomembranes, 17(3), pp.171-184.

Shahu, J. T. \& Reddy, Y. R. 2011. Clayey soil reinforced with stone column group: model tests and analyses. Journal of Geotechnical and Geoenvironmental Engineering, 137(12), pp.1265-1274. 
Sivakumar, V., Boyd, J. L., Black, J. A. \& McNeil, J. A. 2010. Effects of granular columns in compacted fills. Proceedings of the Institution of Civil Engineers-Geotechnical Engineering, 163(4), pp.189-196.

Unnikrishnan, N., Rajagopal, K. \& Krishnaswamy, N. R. 2002. Behaviour of reinforced clay under monotonic and cyclic loading. Geotextiles and Geomembranes, 20(2), pp.117-133. 